Review

\title{
Prophylactic and Therapeutic Vaccination against Hepatitis C Virus (HCV): Developments and Future Perspectives
}

\section{Marian E. Major}

Division of Viral Products, Center for Biologics, Food and Drug Administration, Bldg29A/Rm1D10, 8800 Rockville Pike, Bethesda, MD 20892,USA; E-mail: marian.major@fda.hhs.gov;

Tel.: +1-301-827-1881; Fax: +1-301-496-1810

Received: 3 June 2009; in revised form: 25 July 2009 / Accepted: 11 August 2009 /

Published: 12 August 2009

\begin{abstract}
Studies in patients and chimpanzees that spontaneously clear Hepatitis C Virus (HCV) have demonstrated that natural immunity to the virus is induced during primary infections and that this immunity can be cross protective. These discoveries led to optimism regarding prophylactic HCV vaccines and a number of studies in the chimpanzee model have been performed, all of which resulted in modified infections after challenge but did not always prevent persistence of the virus. Therapeutic vaccine strategies have also been pursued in an effort to reduce the costs and side effects associated with anti-viral drug treatment. This review summarizes the studies performed thus far in both patients and chimpanzees for prophylactic and therapeutic vaccination, assesses the progress made and future perspectives.
\end{abstract}

Keywords: vaccine; immune responses; immunotherapy; T cells; neutralizing antibody

\section{Introduction}

Hepatitis $\mathrm{C}$ virus (HCV) is an enveloped virus with a single stranded, plus sense RNA genome. The RNA ( $\sim 9.6 \mathrm{~kb}$ in length) consists of a $\sim 341$-base $5^{\prime}$ non-translated region (NTR), a single open reading frame encoding all virus-specific proteins ( $\sim 3011$ amino acids), and a 3' NTR. Translation of the genome RNA is cap-independent and mediated by the 5' NTR which functions as an internal ribosome entry site. The resulting polyprotein is cleaved, both co- and post-translationally by host and viral proteases. The structural proteins, which include the core and the envelope glycoproteins (E1, E2) are located at the N-terminus; the nonstructural (NS) components are located in the carboxy terminus two 
thirds and include p7, NS2-3 (a protease), NS3 (a serine protease and RNA helicase), NS4A, NS4B, NS5A and NS5B (an RNA-dependent RNA polymerase) [1,2].

Transmission of HCV is typically by the parenteral route, but per mucosal transmission such as sexual and maternal infant transmission do occur. Persistent infections caused by HCV occur in $70-80 \%$ of the acutely infected population, the majority of which will develop chronic hepatitis and will be at risk for cirrhosis, end-stage liver disease and/or hepatocellular carcinoma [3]. HCV is associated with $40-60 \%$ of chronic liver disease in the U.S. Of these patients, one third goes on to develop progressive fibrosis and cirrhosis [4] making hepatitis $\mathrm{C}$ the major disease leading to liver transplantation [3]. Hepatitis C is now the major cause of hepatocellular carcinoma (HCC) in Japan, having displaced hepatitis $\mathrm{B}$ and, according to the $\mathrm{CDC}$, there are 8,000-10,000 deaths each year in the U.S. alone due to HCV-associated cirrhosis and cancer.

Significant progress has been made in the therapy of chronic hepatitis C. Current therapies with pegylated IFN- $\alpha$ and Ribavirin clear HCV infection in approximately $50 \%$ of cases, but treatment remains very expensive, requires 6-12 months of therapy, and carries a significant risk of serious side effects [5-7]. Currently, there are about 25,000 new HCV infections each year in the U.S. alone, making the development of a prophylactic vaccine against this virus imperative. An immunologic approach to treatment is also sought to either replace or enhance drug treatment. Major benefits in expenses and logistics would be gained if it were possible to treat a chronic HCV patient with 2-3 doses of a therapeutic vaccine as opposed to 6 to 12 months of combination IFN and drug therapy.

In this review the current understanding of immune responses that are induced during primary and secondary infections with $\mathrm{HCV}$ and the efficacy of protective immune responses induced with prophylactic vaccine candidates in pre-clinical studies using chimpanzees will be discussed. The feasibility and progress of immunotherapeutic studies in humans and non-human primates designed to treat patients chronically infected with $\mathrm{HCV}$ will also be discussed.

\section{Genetic Diversity of HCV}

In general, during replication of RNA viruses errors are randomly introduced into the genome by the RNA-dependent RNA polymerase (RdRp) and, due to the lack of proof-reading function in these enzymes, remain uncorrected. Many of these misincorporations are lethal for the virus and go undetected, others are silent, leading to a change in the nucleotide sequence but maintaining the amino acid residue. A third type of mutation changes the amino acid sequence. These non-lethal mutations have either no effect on virulence or confer an advantage to the virus such that it can replicate more efficiently, evade the host immune response or develop drug resistance. Thus, variant RNA genomes or polypeptide sequences can evolve establishing, in the case of $\mathrm{HCV}$, the co-existence of several closely related but distinct viruses within a single host, referred to as a quasispecies population.

Nucleotide sequences of viral isolates have been studied extensively and six major genotypes (designated 1-6) have been defined, differing by 30-35\% over the complete genome [8]. The greatest genetic variability is observed in the E1 and E2 glycoproteins and the NS5A region with higher sequence conservation observed in the NS3 and NS5B regions, the core gene and the 5'UTR [8]. Within each of the six major genotypes there exist more closely related subtypes (designated 1a, 1b, 2a, $3 a$ etc.) differing from each other by $20-25 \%$ at the nucleotide level [8]. An unusually high degree of 
amino acid variation has been observed in the $\mathrm{N}$ terminus of the $\mathrm{E} 2$ protein $[9,10]$. This hypervariable region, referred to as HVR1, is located between aa 384-410 of the polyprotein (aa1-27 of E2). The HVR1 varies enormously both within any one isolate and between different genotypes [11,12]. Secondary structure predictions indicate the HVR1 of HCV is highly unstructured [13], which is consistent with a tolerance for the degree of sequence variation observed, and has been shown to be dispensable for replication and in vivo infection [14]. The HVR1 has also been shown to contain neutralizing antibody epitopes [15] and observations that specific antibody to this region changes during the course of chronic infections suggests that HVR1 is subject to immune pressure with the potential for escape mutants [13,16-18].

HCV sequences are continually evolving during an infection due to the error-prone NS5B RdRp, which generates an estimated $10^{-5}$ mutations/nucleotide/replication [19], and the high production and clearance rate of the virus, estimated at $10^{12}$ virions per day [20]. Immune escape has been shown directly and indirectly in a number of instances for natural infections in both T-cell [21-23] and B-cell [16,18,24] epitopes. Immune escape in CD4+ [25] and CD8+ [26] T-cell epitopes have also been shown in chimpanzees following failure of T-cell based vaccines, although immune escape from neutralizing antibody has not yet been demonstrated in vaccine studies.

$\mathrm{HCV}$ genetic diversity poses problems for vaccine development from the perspective of target antigens and the potential for escape from the vaccine-induced immune response. The variation in virus isolates has led to suggestions that a vaccine would need to be tailored to all six genotypes to be effective. However, patient plasma samples and monoclonal antibodies have been identified that are capable of cross-neutralizing a number of different genotypes [27-30] suggesting an effective cross reactive vaccine targeting the envelope region could be designed. T-cell-based vaccines have also received a great deal of focus partly due to the role of T-cells in natural clearance (see Section 4 below) but also because these vaccines can target the more conserved regions of HCV. Both of these approaches for the development of prophylactic vaccines against HCV are discussed more fully in Section 5.

\section{HCV Kinetics During Primary and Secondary Infections}

In primary $\mathrm{HCV}$ infections acute hepatitis develops at $\sim 8-14$ weeks, when serum ALT levels increase and $\mathrm{HCV}$-specific T-cells become detectable in the liver. The replication kinetics are characterized by a rapid (logarithmic) viral increase during the first 1-2 weeks, with a mean doubling time of $\sim 0.5$ days, after which the viral increase slows to a mean half-life of 7.5 days [31]. Concomitant with ALT elevations viral titers rapidly decline at $\sim 8-14$ weeks [31-33] at which point $\mathrm{CD}^{+} \mathrm{T}$-cell responses and increased intrahepatic IFN- $\gamma$ expression can be detected $[31,32,34,35]$, which is associated with T-cell mediated immune responses. Early studies on HCV infections in chimpanzees and humans demonstrated that individuals that had recovered from a primary infection with the virus could be reinfected with homologous or heterologous strains [36,37]. However, subsequent studies in humans and chimpanzees have demonstrated that although reinfection does occur the viral kinetics are very different with immediate control of viral replication and rapid clearance in the majority of cases [38-40], although persistent infections following prior clearance can occur [41]. These data support the argument that adaptive immune responses are induced during a 
primary infection and that these responses can modify secondary infections and clear HCV more rapidly. Studies on viral kinetics have shown that the second infection is of short duration with a reduced viral titer in the blood and liver in comparison to the initial infection and reduced hepatic inflammation as indicated by alanine amino transferase levels (ALT) (Figure 1) [38,39]. Importantly, this level of protection also appears to be effective against other genotypes $[42,43]$.

Figure 1. Schematic representation of primary and secondary infections with hepatitis $\mathrm{C}$ virus. Viral RNA titers in the serum are shown in blue; serum alanine aminotransferase (ALT) levels indicative of hepatitis are shown as a black solid line; seroconversion to anti$\mathrm{HCV}$ antibodies as assessed by commercial assays is shown in red.

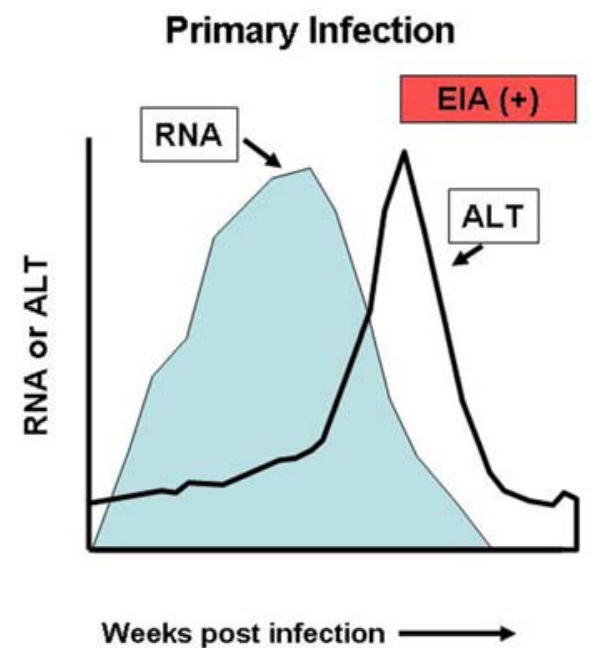

\section{Secondary Infection}

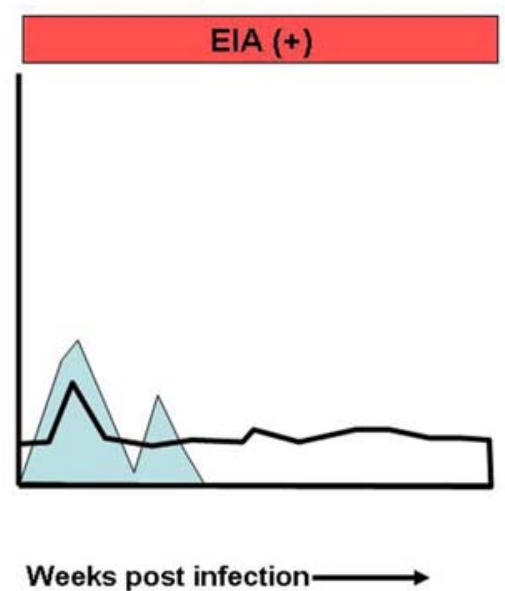

\section{Immune Correlates of Viral Clearance}

Both CD4+ and CD8+ T-cells have been shown to play a major role in clearance of HCV during primary and secondary infections with strong support for the involvement of immune responses to HCV NS3 in clearance of acute infection [44-49] (reviewed in [50]). After spontaneous recovery from $\mathrm{HCV}$, resting HCV-specific memory T-cells can be detected in the peripheral blood of patients for decades, in many cases in the absence of detectable HCV antibodies [51]. HCV-specific cellular immune responses also persist in the liver, as demonstrated in recovered chimpanzees, and mediate protective immunity on reinfection $[34,35,39,52,53]$. The essential role of neutralizing antibody in controlling viral replication during primary or secondary infections is still unclear. Until the development of lentiviral/HCV pseudotype particle systems bearing the HCV envelope glycoproteins on the particle surface $[54,55]$ the neutralizing ability of anti-envelope antibodies had been difficult to measure. More recently a cell culture system for HCV was developed using a genotype 2a virus $[56,57]$ and although the 2 a genotype virus remains the only genome able to robustly replicate and produce infectious virus in vitro this system has been used to generate chimeric viruses expressing the envelope proteins of all HCV genotypes [58-61]. Using these tools it has been shown that patients produce antibodies that neutralize infectivity in vitro and can cross neutralize a number of different genotypes [27,62]. High titers of neutralizing antibody are not produced until the chronic phase of the infection [27] and although the induction of neutralizing antibodies has in some cases been associated 
with clearance of the virus [63-65], it appears such antibodies may not be an absolute requirement for clearance $[27,66]$. Despite conflicting reports regarding the importance of antibodies to the surface glycoproteins of HCV during acute infections such antibodies have been shown to neutralize or control HCV RNA levels in a number of in vivo experiments [67-69] and neutralize virus or virus-like particles using in vitro systems $[24,54,55,62,66]$ and should still be considered as an important component of any $\mathrm{HCV}$ vaccine.

\section{Prophylactic Vaccines}

A list of published HCV prophylactic vaccine studies in chimpanzees is shown in Table 1; these studies can roughly be divided into vaccines designed to induce T-cell responses, targeting nonstructural proteins, or those primarily designed to induce neutralizing antibody responses, targeting the envelope region of the virus. The majority of vaccine studies have used homologous virus to challenge, i.e. the same genotype as that represented by the vaccine. In some publications the challenge virus is referred to as "heterologous" where a different variant of the same genotype has been used with approximately $7 \%$ diversity from the vaccine-based sequence. For consistency with terms of genetic diversity, in Table 1 "heterologous" has only been used to describe the challenge virus when a different genotype was used. This occurred in only one vaccine study performed by Folgori et al. [26] where the vaccine used genotype 1a sequences and the challenge was performed with a genotype $1 \mathrm{~b}$ virus. Youn et al. [70] used a number of different genotypes to reinfect chimpanzees that had recovered from the primary challenge following vaccination. However, as these challenges followed clearance of a primary infection after vaccination, the extent to which the post-vaccine primary infection contributed to control or protection from the heterologous challenge can not be differentiated from the effect of the vaccine.

The majority of vaccine studies have used small numbers of chimpanzees (between one and six animals per study); however, important information can be gained from each one of these studies. Of particular importance is the fact that every prophylactic vaccine study published has successfully induced HCV-specific immune responses and has also led to modification of HCV replication soon after challenge, indicating that the vaccines have been effective at priming antibody or T-cell responses that can inhibit viral replication. However, despite this initial control persistent infections have developed in a number of the vaccinated chimpanzees. The persistence in some cases has been associated with immune escape in CD4+ [25] or CD8+ [26] T-cells and with higher viral mutation rates [71], suggesting that in cases where the immune response cannot rapidly clear the virus there remains an environment for selective pressure. Interestingly, the vaccines that seem to have had the greatest success at protection or leading to resolved infections have included all or part of the HCV envelope region inducing primarily either neutralizing antibody [72-74] or E1E2 T-cell responses $[70,75]$. These data suggest that neutralizing antibodies can play a role in protection but also that this region may contain $\mathrm{T}$-cell epitopes that are important for clearance. 
Table 1. Prophylactic HCV Vaccine Studies in Chimpanzees.

\begin{tabular}{|c|c|c|c|c|}
\hline $\begin{array}{c}\text { Vaccine } \\
\text { (Genotype sequence used) } \\
\text { (Number of animals vaccinated) } \\
\end{array}$ & Immunogenicity & $\begin{array}{c}\text { Challenge } \\
\text { Inoculum* } \\
\text { Dose (CID50§) } \\
\end{array}$ & Outcome & Ref. \\
\hline $\begin{array}{l}\text { Recombinant gpE1/gpE2 in Oil/water } \\
\text { adjuvants } \\
\text { (Genotype 1a) } \\
(\mathrm{N}=21)\end{array}$ & $\begin{array}{l}\text { Induced antibodies } \\
\text { to E1E2 }\end{array}$ & $\begin{array}{l}\text { Genotype 1a } \\
\text { Homologous } \\
10 \text { to } 100 \text { CID50 }\end{array}$ & $\begin{array}{l}\text { Protects against infection or } \\
\text { chronic infection } \\
5 \text { protected from infection } \\
14 \text { resolved infection } \\
2 \text { developed persistent infection }\end{array}$ & $\begin{array}{l}772] \\
{[73]}\end{array}$ \\
\hline $\begin{array}{l}\text { DNA vaccine expressing E2 protein } \\
\text { (Genotype 1a) } \\
(\mathrm{N}=2)\end{array}$ & $\begin{array}{l}\text { Induced antibody } \\
\text { and } \mathrm{T} \text { cell responses } \\
\text { to } \mathrm{E} 2 \text {. }\end{array}$ & $\begin{array}{l}\text { Genotype 1a } \\
\text { Homologous } \\
\text { 100CID50 }\end{array}$ & $\begin{array}{l}\text { Modifies infection, protects from } \\
\text { chronic infection } \\
2 \text { resolved infection }\end{array}$ & {$[74]$} \\
\hline $\begin{array}{l}\text { Recombinant gpE1/gpE2 in oil/water adjuvants } \\
\text { (Genotype 1a) } \\
(\mathrm{N}=1)\end{array}$ & $\begin{array}{l}\text { Induced antibodies } \\
\text { and cellular } \\
\text { responses to E1E2 }\end{array}$ & $\begin{array}{l}\text { Genotype 1a } \\
\text { Homologous } \\
\text { 100CID50 } \\
\end{array}$ & $\begin{array}{l}\text { Delayed/modified infection } \\
1 \text { developed persistent infection }\end{array}$ & {$[76]$} \\
\hline $\begin{array}{l}\text { DNA prime and protein boost (using C, gpE1, } \\
\text { gpE2 and NS3) } \\
\text { (Genotypes 1a (core, NS3) and 1b (core, E1E2, } \\
\text { NS3)) } \\
(\mathrm{N}=2)\end{array}$ & $\begin{array}{l}\text { Induced specific } \mathrm{T} \text { - } \\
\text { cell responses and } \\
\text { antibody to } \mathrm{E} 1 \text { and } \\
\text { E2. }\end{array}$ & $\begin{array}{l}\text { Genotype 1b } \\
\text { Homologous } \\
25 \text { CID50 }\end{array}$ & $\begin{array}{l}\text { Modifies infection, protects from } \\
\text { chronic infection } \\
1 \text { resolved infection } \\
1 \text { developed persistent infection }\end{array}$ & {$[77]$} \\
\hline $\begin{array}{l}\text { DNA prime and Recombinant Adenovirus } \\
\text { expressing core, E1,E2 and NS3 to NS5B } \\
(\text { Genotype } 1 b) \\
(\mathrm{N}=6)\end{array}$ & $\begin{array}{l}\text { Induced specific } \mathrm{T}- \\
\text { cell responses and } \\
\text { anti-E2 antibody } \\
\text { (neutralizing) }\end{array}$ & $\begin{array}{l}\text { Genotype } 1 \mathrm{~b} \\
\text { Homologous } \\
\text { 100CID50 }\end{array}$ & $\begin{array}{l}\text { Modifies infection, protects from } \\
\text { chronic infection } \\
1 \text { protected from infection } \\
1 \text { resolved infection } \\
4 \text { developed persistent infection }\end{array}$ & {$[78]$} \\
\hline $\begin{array}{l}\text { DNA prime and Recombinant VV expressing } \\
\text { NS3,NS5A,NS5B } \\
\text { (Genotype 1a) } \\
(\mathrm{N}=1)\end{array}$ & $\begin{array}{l}\text { Induced specific T- } \\
\text { cell responses }\end{array}$ & $\begin{array}{l}\text { Genotype 1a } \\
\text { Homologous } \\
\text { 100CID50 }\end{array}$ & $\begin{array}{l}\text { Modifies infection } \\
1 \text { developed persistent infection }\end{array}$ & {$[25]$} \\
\hline $\begin{array}{l}\text { DNA prime and Recombinant Adenovirus } \\
\text { expressing NS3 to NS5B } \\
\text { (Genotype } 1 \mathrm{~b}) \\
(\mathrm{N}=5)\end{array}$ & $\begin{array}{l}\text { Induced specific T- } \\
\text { cell responses }\end{array}$ & $\begin{array}{l}\text { Genotype 1a } \\
\text { Heterologous } \\
100 \text { CID50 }\end{array}$ & $\begin{array}{l}\text { Modifies infection, protects from } \\
\text { chronic infection } \\
4 \text { resolved infection } \\
1 \text { developed persistent infection }\end{array}$ & {$[26]$} \\
\hline $\begin{array}{l}\text { DNA prime and rMVA boost (using C, gpE1, } \\
\text { gpE2 and NS3) } \\
(\text { Genotype } 1 b) \\
(\mathrm{N}=4)\end{array}$ & $\begin{array}{l}\text { Induced specific } \mathrm{T} \text { - } \\
\text { cell responses and } \\
\text { antibody to } \mathrm{E} 1 \text { and } \\
\text { E2. }\end{array}$ & $\begin{array}{l}\text { Genotype } 1 \mathrm{~b} \\
\text { Homologous } \\
25 \text { CID50 }\end{array}$ & $\begin{array}{l}\text { Modifies infection, protects from } \\
\text { chronic infection } \\
1 \text { resolved infection } \\
3 \text { developed persistent infection }\end{array}$ & [79] \\
\hline $\begin{array}{l}\text { Recombinant VLPs containing C, E1 and E2 } \\
(\text { Genotype } 1 b) \\
(\mathrm{N}=4)\end{array}$ & $\begin{array}{l}\text { Induced specific T- } \\
\text { cell responses. No } \\
\text { detectable anti- } \\
\text { E1E2 response. }\end{array}$ & $\begin{array}{l}\text { Genotype 1b } \\
\text { Homologous } \\
\text { 100CID50 }\end{array}$ & $\begin{array}{l}\text { Modifies infection, protects from } \\
\text { chronic infection } \\
4 \text { resolved infection }\end{array}$ & {$[75]$} \\
\hline $\begin{array}{l}\text { Recombinant VV core, E1, E2, p7, NS2 and } \\
\text { NS3 } \\
\text { (Genotype } 1 \mathrm{~b}) \\
(\mathrm{N}=4)\end{array}$ & $\begin{array}{l}\text { Induced specific T- } \\
\text { cell responses. } \\
\text { Weak anti-E1E2 } \\
\text { response. }\end{array}$ & $\begin{array}{l}\text { Genotype } 1 \mathrm{~b} \\
\text { Homologous } \\
2.5 \text { and } \\
24 \text { CID50 } \dagger\end{array}$ & $\begin{array}{l}\text { Modifies infection, protects from } \\
\text { chronic infection } \\
4 \text { resolved infection }\end{array}$ & {$[70]$} \\
\hline $\begin{array}{l}\text { DNA prime and Recombinant Adenovirus } \\
\text { expressing NS3,NS5A,NS5B } \\
(\text { Genotype 1a) } \\
(\mathrm{N}=2)\end{array}$ & $\begin{array}{l}\text { Induced specific T- } \\
\text { cell responses }\end{array}$ & $\begin{array}{l}\text { Genotype 1a } \\
\text { Homologous } \\
\text { 100CID50 }\end{array}$ & $\begin{array}{l}\text { Modifies infection or protects } \\
\text { from chronic infection } \\
1 \text { resolved infection } \\
1 \text { developed persistent infection }\end{array}$ & [71] \\
\hline
\end{tabular}

* Homologous and heterologous refer to the same or different genotype, respectively; $\S$ CID50=50\% chimpanzee infectious doses; $\uparrow$ Animals erroneously received 2.5CID50 which did not lead to infection in control animals. Animals were then challenged with 24CID50.

A major question surrounding HCV prophylactic vaccines is what should be the expected outcome following exposure in vaccinated individuals? Is sterilizing immunity a realistic goal or should rapid control of viral replication followed by clearance be an acceptable endpoint? Given our current knowledge of viral kinetics in secondary infections and results of a relatively large number of different vaccine studies in chimpanzees it appears that sterilizing immunity may not be achievable or guaranteed in $100 \%$ of cases. It has been shown that a number of well-established, highly important, 
licensed vaccines do not confer sterilizing immunity (e.g. measles [80], influenza [81], polio [82]) in that viral replication can be shown in vaccinees following exposure using cell culture or antigen studies. However, it has been clearly demonstrated that these vaccines induce immune responses that protect against illness, reduce the level of viral replication and have been enormously successful at controlling disease. The current methods that have been developed for detecting HCV in plasma are PCR-based assays that can detect very low amounts of virus, such as the transcription-mediated nucleic acid amplification assay (TMA) which can detect as few as $50 \mathrm{HCV}$ RNA copies/mL [83]. These are far more sensitive than assays that were in place many years ago when most of the current vaccines for viral infections were developed. For example, when the hepatitis A (HAV) and hepatitis B (HBV) vaccines were licensed PCR testing had either not been developed or was in its infancy. In the pivotal clinical trials performed for the two main HAV vaccines currently on the market (Havrix ${ }^{\circledR}$ and VAQTA $($ ) a case was defined by the presence of typical signs and symptoms, a diagnostic increase in IgM antibody to hepatitis A, and elevated serum concentrations of alanine aminotransferase $[84,85]$. HBV vaccines have been commercially available since 1982, well before PCR techniques were developed, with vaccine failures defined as the presence of surface antigen or core antibody or the absence of surface antibody [86]. Only recently in clinical trials for Human Papilloma virus (HPV) vaccines was PCR technology used to detect viral DNA but persistent HPV-16 infection was defined as the detection of HPV-16 DNA in samples obtained at two or more visits, with test samples obtained at enrollment, one month after the third vaccination, and every six months thereafter [87]. Therefore, in this most modern of vaccines designed to protect against a persistent viral infection transient viral replication was either acceptable or would have been missed. Similarly, preventing chronic infection with respect to $\mathrm{HCV}$ in the absence of sterilizing immunity may be an acceptable goal for a vaccine as in humans it is chronic persistence of the virus that is mainly associated with pathogenesis and the development of serious liver conditions [88,89].

Antibody Based Prophylactic Vaccines: The most comprehensive prophylactic vaccine studies have been performed by the Chiron/Novartis group led by Michael Houghton. Using an oil/water adjuvanted $\mathrm{HCV}$ envelope gpE1/gpE2 vaccine designed to induce neutralizing antibodies they have been able to compare the outcome of infection in a relatively large number of vaccinated chimpanzees $(n=21)$ versus untreated controls $(n=24)[72,73]$. This recombinant vaccine was shown to elicit specific antibody and $\mathrm{T}$ cell responses. In animals with high anti-envelope antibody titers apparently sterilizing immunity was achieved, as assessed by RT-PCR, but even in vaccinated animals where virus could be detected by RT-PCR in the plasma post challenge the outcome of infection in vaccinees was more likely to result in clearance than persistence compared with untreated controls $(p=0.002)$. Similarly, chimpanzee studies by Forns et al. [74] using a DNA plasmid to induce anti-E1E2 immune responses found modified infection and rapid clearance of $\mathrm{HCV}$ associated with high anti-envelope antibody titers. Furthermore, Puig et al. [76] showed that coupling a vaccine-induced anti-E1E2 antibody response, using recombinant $\mathrm{gpE} 1 / \mathrm{gpE} 2$, with natural immunity resulting from clearance of the primary infection in a chimpanzee led to a subclinical infection upon rechallenge [76]. These data provide the most promising indications that antibodies to gpE1/gpE2, possibly coupled with $\mathrm{T}$ cell responses, can be protective by preventing or modifying HCV infection such that the virus can be cleared. However, although a number of neutralizing epitopes in E1 and E2 have been identified 
[28-30,55] and neutralizing antibodies have been raised in vaccinated chimpanzees $[76,78,90]$ whether sterilizing immunity is consistently possible or what levels of in vivo titers are required to achieve either sterilizing immunity or successful modification of infection such that clearance is always achieved is still unknown.

The greatest challenge to neutralizing antibody-based vaccines when using a monotypic antigen for immunization is the generation of heterologous protection that can neutralize more than one genotype of HCV. Zhang et al. [90] recently showed that heterologous neutralizing ability is present in plasma from chimpanzees vaccinated with monotypic antigen but cross-neutralization could only be revealed when interfering antibodies specific to an epitope adjacent to a conserved neutralizing epitope in E2 were blocked such that the antibodies specific to the conserved region could be functional [90,91]. These findings have significant implications for development of an E1E2-based vaccine suggesting that the removal of specific immunogenic but non-neutralizing regions from a recombinant E1E2 vaccine could lead to the induction of a cross-neutralizing immune response. Further studies of this type need to be performed analyzing antibody profiles induced following vaccination and natural infection in order to dissect out which antibodies are effective for neutralization and which are immunogenic but non-neutralizing.

T-cell based Prophylactic Vaccines: Since the demonstration that T-cells are important for clearance of HCV a great deal of focus has been placed on developing vaccines that will induce T-cell responses to HCV proteins. These types of vaccines have an advantage over vaccines that focus on inducing immune responses to the envelope proteins as more conserved regions of the virus can be targeted potentially generating a more heterologous immune response capable of protecting against a number of HCV genotypes.

A number of approaches have been used to generate T-cell responses against HCV antigens in chimpanzee studies (Table 1); these include the use of virus-like particles and defective or attenuated viral vectors with or without priming of the immune system with DNA plasmids. The use of HCV virus-like particles produced in insect cells has proved successful at inducing effective HCV-specific immune responses, although interestingly the responses to the structural proteins were mainly T-cell specific with little or no neutralizing antibody detected [75]. All of the chimpanzee vaccine studies published to date have been successful at inducing specific immune responses to the target antigens and all have resulted in modification of the HCV infection and early control of replication following challenge with virus. The HCV-specific T-cells induced have been shown to produce IFN- $\gamma$ and in many cases additional cytokines such as IL-2 and IL-4. However, eliciting broad CD4+ and/or CD8+ T-cell responses has not always prevented persistent infections in the animals studied. In some cases the development of persistent infections have been associated with lower immune responses compared to other vaccinees [26,77] or higher levels of viral mutation rates and immune escape [25,26,71]. Although it is difficult to quantitatively compare T-cell assays between different groups and laboratories the vaccine studies performed using the chimpanzee model seem to have induced more robust immune responses than those routinely detected in recovered patients or chimpanzees suggesting the quality of the immune response is more important than a quantitatively strong immune response for rapid clearance of the virus. These findings emphasize the importance of the chimpanzee model for testing the efficacy of a vaccine-induced response before proceeding to clinical trials. In the 
next generation of vaccine studies detailed analyses need to be performed of T-cell phenotypes induced and functional markers of protection such as homing profiles, central and effector memory phenotypes, T helper function and proliferation using markers such as CCR7, CD28, CD62L and CD45RA (reviewed [92]). It is possible that in cases where T-cell vaccines fail to clear the virus the induced HCV-specific cells are only secreting a single cytokine, such as IFN- $\gamma$, while it is necessary to induce polyfunctional cells that secrete multiple cytokines, such as IL-2 and TNF- $\alpha$, as has been achieved with HIV vaccines [93]. These types of studies require large numbers of cells but are necessary before vaccines move into clinical trials involving any populations at risk for infection with HCV.

The types of viral vectors used for HCV T-cell vaccines are common to a number of strategies used for other vaccine targets such as HIV and include adenovirus [26,71,78] and vaccinia virus $[25,70,77,79]$ vectors. Transferring these viral vectors to human clinical trials may be challenging due to pre-existing immunity or adverse side effects. Adenovirus vector modifications have been extensively explored in the vaccine field and include the use of alternative serotypes and genetic modifications [26,94]. In addition, a highly attenuated strain of vaccinia virus (Modified Vaccinia Ankara, MVA) has been developed which has proved to be immunogenic and as effective at eliciting immune responses as wild type virus $[95,96]$. The studies in chimpanzees to date have mainly been performed in order to establish whether a vaccine-induced T-cell response can be effective at modifying HCV infection and replicating the type of viral kinetics seen in recovered/rechallenged animals. A greater number of vector and delivery systems have been explored in animal systems other than the chimpanzee model and have been successful at inducing HCV-specific immune responses. Replication-defective alphavirus particles have been used in mice to induce NS3-specific cytotoxic T-cell responses [97] or in combination with Th1-adjuvanted proteins to induce neutralizing antibodies as well as broad CD4+ and CD8+ T-cell responses to non-structural proteins [98]. Alphaviruses are attractive as gene delivery systems due to high levels of foreign gene expression [99]; dsRNA intermediates, which can stimulate the innate immune system [100]; and the potential for cross presentation of antigen due to cytopathic effect. However, there are concerns regarding safety of Venezuelan equine encephalitis virus replicons and the replication levels and immunogenicity of Sindbis virus in humans [101]. An adenovirus vector-based minigene vaccine encompassing four domains of the NS3, NS4 and NS5B proteins that contain multiple class I/II restricted epitopes also induced strong and broad HCV-specific T-cell responses in HLA-A2 transgenic mice [102] and may prove promising as a tool for inducing cross-reactive responses. However, as challenge experiments have not been performed with these newer systems to determine efficacy caution needs to be taken in assessing potential success following scale-up to chimpanzees or humans in the clinical setting.

\section{Therapeutic Vaccines}

Great progress has been made in the therapy for HCV but the current standard of care for chronic infections still remains a combination of pegylated IFN- $\alpha$ and Ribavirin for 6-12 months. Previously clinical results showed an almost $100 \%$ sustained viral response rate in patients when treatment is initiated early (89 days) after infection [103] as compared with 50\% of cases in the chronic phase [7]. However despite promising results for the treatment of new infections there still remains the problem 
of treating the $\sim 170$ million chronically infected patients worldwide, many of whom have not responded to IFN/Ribavirin treatment in the past. With the advances in cell culture systems to study $\mathrm{HCV}$ replication $[56,57,104,105]$ there has been a great deal of focus on the development of drugs to specifically inhibit viral enzymes such as the protease; helicase; and RNA-dependent RNA polymerase. In addition there is a role for therapeutic strategies to enhance HCV-specific immune responses that may be used alone or in conjunction with existing or new antiviral therapies.

A number of diverse therapeutic vaccine trails have been performed; these are listed in Table 2. Unlike prophylactic vaccines these have been carried out in HCV infected patients or healthy volunteers in a clinical setting. The approach of therapeutic vaccines has been similar to prophylactic vaccines in that the major goal has been to enhance HCV-specific T-cell responses although enhancement of envelope antibody responses has also been included in a number of studies. The strategies have included using recombinant proteins (core or E1) adjuvanted with ISCOMATRIX or alum. ISCOMATRIX is an adjuvant that forms a cage-like structure resulting in the induction of antibody and T-cell responses. Other strategies have used peptide vaccines; DNA vaccines, MVA vectors, and heat-inactivated antigens from $\mathrm{HCV}$-infected donors. The current therapeutic vaccine trails to date have not succeeded in clearing HCV infections or achieving sustained reductions in viral titers. However, the studies have all successfully stimulated HCV-specific immune responses with transient reductions in viral RNA titers [106-108] and possible stabilization or improvement in liver histology or liver enzymes [109-111] in subsets of patients. Recently, the therapeutic peptide vaccine IC41 was added to pegylated IFN/Ribavirin treatment [112] in an attempt to decrease the relapse rate in patients receiving standard therapy. Although the IC41 vaccine did not prevent HCV-RNA relapse, specific T-cell responses were induced and were associated with lower relapse rates.

In addition to human therapeutic vaccine trials some in vitro studies have been performed using peripheral blood mononuclear cells from HCV infected patients [113,114]. One study used synthetic self-adjuvanting lipopeptides containing a CD4+ helper epitope and an NS5B epitope from HCV together with a ligand for Toll-like receptor 2 on dendritic cells (DCs) [113] for DC-based immunotherapy of HCV infection. The lipopeptides were able to activate monocyte-derived DCs from both healthy and HCV infected patients, the pulsed DCs were also able to activate autologous CD8+ T-cells from an HCV patient. A second study used modified adenovirus recombinants expressing core and NS3 of HCV [114]. The recombinant was able to activate and expand HCV-specific T-cells from $\mathrm{HCV}$-infected donors in vitro. These strategies have yet to be tested in patients for effects on $\mathrm{HCV}$ viral titers but both have promising implications for immunotherapy.

Some strategies used for therapeutic vaccines (e.g. peptide or DNA vaccination) may not be as effective in naïve patients for inducing a de novo immune response compared to persistently infected patients where the immune system has already been primed by the natural infection. However, the same or similar viral vectors, such as MVA, could in principle be used for both types of vaccination strategies. Approaches such as the use of inactivated HCV antigens derived from HCV-infected donors may be considered too high a risk for use in healthy individuals as a prophylactic vaccine although if this proved effective at reducing $\mathrm{HCV}$ titers or clearing the virus recombinant forms of the proteins could be considered for future development. As more information is gained about possible immune dysfunction that may occur in persistently infected patients, therapeutic vaccines may need to be tailored to include specialized immunostimulatory molecules such as ligands for Toll-like receptors or 
vectors that secrete cytokines shown to be poorly expressed by T-cells from chronically infected patients.

Table 2. HCV Immunotherapeutic Vaccine Studies.

\begin{tabular}{|c|c|c|c|c|}
\hline $\begin{array}{c}\text { Vaccine } \\
\text { (Genotype sequence used) }\end{array}$ & $\begin{array}{c}\text { Patient HCV } \\
\text { Genotype }\end{array}$ & Immunogenicity & Outcome & Ref. \\
\hline $\begin{array}{l}\text { Alum-adjuvanted recombinant } \\
\text { gpE1 protein } \\
\text { (Genotype } 1 \mathrm{~b})\end{array}$ & $\begin{array}{l}\text { *Genotype } 1 \mathrm{a} \\
\text { Genotype } 1 \mathrm{~b}\end{array}$ & $\begin{array}{l}\text { Antibody and T-cell responses in } \\
\text { some healthy volunteers. } \\
\text { Boosts humoral and cellular } \\
\text { responses in a subset of patients }\end{array}$ & May ameliorate hepatitis & $\begin{array}{l}{[109]} \\
{[115]} \\
{[116]}\end{array}$ \\
\hline $\begin{array}{l}\text { Peptide vaccine targeting E1, } \\
\text { E2, NS3 and NS5A. } \\
\text { (Genotype } 1 \mathrm{~b} \text { ) }\end{array}$ & Genotype $1 b$ & $\begin{array}{l}\text { Boosted peptide-specific T-cell } \\
\text { and antibody responses. }\end{array}$ & $\begin{array}{l}\text { Decreased ALT levels } \\
\text { and HCV RNA levels in a } \\
\text { subset of patients. }\end{array}$ & {$[106]$} \\
\hline $\begin{array}{l}\text { DNA vaccine (CIGB-230) } \\
\text { expressing core, E1, E2 plus } \\
\text { recombinant core protein } \\
\text { (Genotype 1b) }\end{array}$ & Genotype $1 b$ & $\begin{array}{l}\text { Boosted neutralizing antibody } \\
\text { responses and T-cell responses in } \\
\text { patients. }\end{array}$ & May ameliorate hepatitis & {$[110]$} \\
\hline $\begin{array}{l}\text { Synthetic peptide vaccine } \\
\text { (core, NS3, NS4) IC41 with or } \\
\text { without poly-L-arginine. } \\
\text { Genotype } 1\end{array}$ & $\begin{array}{l}\text { Genotype } 1 \\
\text { Genotype } 3 \\
\text { Genotype } 4\end{array}$ & $\begin{array}{l}\text { Boosted T-cell responses in } \\
\text { patients. }\end{array}$ & $\begin{array}{l}\text { Transient decline }(>1- \\
\log ) \text { in HCV serum RNA } \\
\text { titers in a subset of } \\
\text { patients. }\end{array}$ & {$[107]$} \\
\hline $\begin{array}{l}\text { V-5 Immunitor - heat- } \\
\text { inactivated HCV antigens from } \\
\text { HCV-infected donors } \\
\text { administered orally in tablet } \\
\text { form. (Genotype not defined) }\end{array}$ & $\begin{array}{l}\text { Genotype not } \\
\text { defined }\end{array}$ & Not measured. & $\begin{array}{l}\text { Decreased liver enzyme } \\
\text { levels. May improve } \\
\text { HCV-associated clinical } \\
\text { symptoms. }\end{array}$ & {$[111]$} \\
\hline $\begin{array}{l}\text { ICOMATRIX-adjuvanted } \\
\text { recombinant core protein } \\
\text { (Genotype 1a) }\end{array}$ & $\begin{array}{l}\text { Healthy } \\
\text { patients used. }\end{array}$ & $\begin{array}{l}\text { Induced HCV-specific immune } \\
\text { responses and } \mathrm{CD}+\mathrm{T} \text {-cell } \\
\text { responses in a subset of patients. }\end{array}$ & $\begin{array}{l}\text { Clinical trial in healthy } \\
\text { adults, no HCV infected } \\
\text { patients tested. }\end{array}$ & $\begin{array}{l}{[117]} \\
{[118]} \\
{[119]}\end{array}$ \\
\hline $\begin{array}{l}\text { MVA expressing NS3, NS4 } \\
\text { and NS5B proteins (Transgene } \\
\text { TG4040). } \\
\text { (Genotype } 1 \mathrm{~b} \text { ) }\end{array}$ & $\begin{array}{l}\text { Genotype not } \\
\text { defined }\end{array}$ & $\begin{array}{l}\text { Boosted HCV-specific immune } \\
\text { responses }\end{array}$ & $\begin{array}{l}\text { Transient decrease in } \\
\text { viral load in a subset of } \\
\text { patients. }\end{array}$ & $\begin{array}{l}{[108]} \\
{[120]} \\
{[121]}\end{array}$ \\
\hline
\end{tabular}

* Cohort consisted of healthy volunteers, and recovered patients in addition to HCV infected patients. Genotype refers to viral genotype in the HCV infected patients only.

The enhancement of HCV-specific immune responses in chronically infected patients is encouraging but further investigation and follow-up of existing clinical trials is required to determine if changes in the observed parameters in treated patients are sustained; if there is immune escape of the circulating virus from the boosted immune response and whether this may contribute to the transient reductions in virus titers; and what impact these strategies may have on patient outcome if combined with current or newly developed antiviral therapy.

\section{Conclusions}

In conclusion, the prospects for HCV vaccines are better today than they have ever been. This is partly due to overall advances in vaccine technology and methods to analyze and characterize immune responses but it is also due to advances in our specific understanding of natural HCV immunity, HCV replication and kinetics and the development of new tools to test antibody immune responses such as 
pseudotype particles and cell culture grown virus. However, there is still a great deal of missing information. We still do not know which types of immune responses correlate with protection or clearance of $\mathrm{HCV}$ during natural infection or the types of immune responses that are present during chronic infections that seem to exert only partial control of HCV. New vaccine studies also need to include higher level immunological analyses examining multifunctional activities of T-cells and T-cell phenotypes. It is still too early to assess how cross protective any vaccine candidate may be, mainly due to the difficulties of challenging large numbers of chimpanzees with multiple heterologous genotypes. Our current understanding from chimpanzee rechallenge studies and human exposure studies certainly indicates that natural cross protective immunity is present following a single genotype infection, suggesting that a multivalent vaccine tailored to all six genotypes would not be necessary. The development of a small animal model that is immunocompetent would advance the field enormously although care should always be taken in extrapolating data to humans as many immune response studies in mice have not translated well to humans and primates. We also need to investigate the effects of vaccine-induced immune responses on immune escape and possible persistence of HCV; this applies to both prophylactic and therapeutic vaccines.

\section{Acknowledgements}

The findings and conclusions in this article have not been formally disseminated by the U.S. Food and Drug Administration and should not be construed to represent any Agency determination or policy.

\section{References}

1. Bartenschlager, R.; Frese, M.; Pietschmann, T. Novel insights into hepatitis C virus replication and persistence. Adv. Virus Res. 2004, 63, 71-180.

2. Moradpour, D.; Penin, F.; Rice, C.M. Replication of hepatitis C virus. Nat. Rev. Microbiol. 2007, 5, 453-463.

3. Alter, M.J.; Kruszon-Moran, D.; Nainan, O.V.; McQuillan, G.M.; Gao, F.; Moyer, L.A.; Kaslow, R.A.; Margolis, H.S. The prevalence of hepatitis C virus infection in the United States, 1988 through 1994. N. Engl. J. Med. 1999, 341, 556-562.

4. Liang, T.J.; Rehermann, B.; Seeff, L.B.; Hoofnagle, J.H. Pathogenesis, natural history, treatment, and prevention of hepatitis C. Ann. Intern. Med. 2000, 132, 296-305.

5. Hoofnagle, J.H. Course and outcome of hepatitis C. Hepatology 2002, 36, S21-S29.

6. Manns, M.P.; McHutchison, J.G.; Gordon, S.C.; Rustgi, V.K.; Shiffman, M.; Reindollar, R.; Goodman, Z.D.; Koury, K.; Ling, M.; Albrecht, J.K. Peginterferon alfa-2b plus ribavirin compared with interferon alfa-2b plus ribavirin for initial treatment of chronic hepatitis $\mathrm{C}$ : a randomised trial. Lancet 2001, 358, 958-965.

7. Fried, M.W.; Shiffman, M.L.; Reddy, K.R.; Smith, C.; Marinos, G.; Goncales, F.L., Jr.; Haussinger, D.; Diago, M.; Carosi, G.; Dhumeaux, D.; Craxi, A.; Lin, A.; Hoffman, J.; Yu, J. Peginterferon alfa-2a plus ribavirin for chronic hepatitis C virus infection. N. Engl. J. Med. 2002, 347, 975-982. 
8. Simmonds, P.; Bukh, J.; Combet, C.; Deleage, G.; Enomoto, N.; Feinstone, S.; Halfon, P.; Inchauspe, G.; Kuiken, C.; Maertens, G.; Mizokami, M.; Murphy, D.G.; Okamoto, H.; Pawlotsky, J.M.; Penin, F.; Sablon, E.; Shin, I.; Stuyver, L.J.; Thiel, H.J.; Viazov, S.; Weiner, A.J.; Widell, A. Consensus proposals for a unified system of nomenclature of hepatitis $\mathrm{C}$ virus genotypes. Hepatology 2005, 42, 962-973.

9. Mizushima, H.; Hijikata, M.; Tanji, Y.; Kimura, K.; Shimotohno, K. Analysis of N-terminal processing of hepatitis C virus nonstructural protein 2. J. Virol. 1994, 68, 2731-2734.

10. Weiner, A.J.; Brauer, M.J.; Rosenblatt, J.; Richman, K.H.; Tung, J.; Crawford, K.; Bonino, F.; Saracco, G.; Choo, Q.L.; Houghton, M. Variable and hypervariable domains are found in the regions of $\mathrm{HCV}$ corresponding to the flavivirus envelope and NS1 proteins and the pestivirus envelope glycoproteins. Virology 1991, 180, 842-848.

11. Sekiya, H.; Kato, N.; Ootsuyama, Y.; Nakazawa, T.; Yamauchi, K.; Shimotohno, K. Genetic alterations of the putative envelope proteins encoding region of the hepatitis $\mathrm{C}$ virus in the progression to relapsed phase from acute hepatitis: humoral immune response to hypervariable region 1. Int. J. Cancer 1994, 57, 664-670.

12. Major, M.E.; Feinstone, S.M. The molecular virology of hepatitis C. Hepatology 1997, 25, 1527-1538.

13. Taniguchi, S.; Okamoto, H.; Sakamoto, M.; Kojima, M.; Tsuda, F.; Tanaka, T.; Munekata, E.; Muchmore, E.E.; Peterson, D.A.; Mishiro, S. A structurally flexible and antigenically variable Nterminal domain of the hepatitis C virus E2/NS1 protein: implication for an escape from antibody. Virology 1993, 195, 297-301.

14. Forns, X.; Thimme, R.; Govindarajan, S.; Emerson, S.U.; Purcell, R.H.; Chisari, F.V.; Bukh, J. Hepatitis $\mathrm{C}$ virus lacking the hypervariable region 1 of the second envelope protein is infectious and causes acute resolving or persistent infection in chimpanzees. Proc. Natl. Acad. Sci. USA 2000, 97, 13318-13323.

15. Farci, P.; Shimoda, A.; Wong, D.; Cabezon, T.; De Gioannis, D.; Strazzera, A.; Shimizu, Y.; Shapiro, M.; Alter, H.J.; Purcell, R.H. Prevention of hepatitis C virus infection in chimpanzees by hyperimmune serum against the hypervariable region 1 of the envelope 2 protein. Proc. Natl. Acad. Sci. USA 1996, 93, 15394-15399.

16. Weiner, A.J.; Geysen, H.M.; Christopherson, C.; Hall, J.E.; Mason, T.J.; Saracco, G.; Bonino, F.; Crawford, K.; Marion, C.D.; Crawford, K.A.; Brunetto, M.; Barr, P.J.; Miyamura, T.; McHutchinson, J.; Houghton, M. Evidence for immune selection of hepatitis C virus (HCV) putative envelope glycoprotein variants: Potential role in chronic HCV infections. Proc. Natl. Acad. Sci. USA 1992, 89, 3468-3472.

17. Kato, N.; Sekiya, H.; Ootsuyama, Y.; Nakazawa, T.; Hijikata, M.; Ohkoshi, S.; Shimotohno, K. Humoral immune response to hypervariable region 1 of the putative envelope glycoprotein (gp70) of hepatitis C virus. J. Virol. 1993, 67, 3923-3930.

18. Shimizu, Y.K.; Hijikata, M.; Iwamoto, A.; Alter, H.J.; Purcell, R.H.; Yoshikura, H. Neutralizing antibodies against hepatitis $\mathrm{C}$ virus and the emergence of neutralization escape mutant viruses. $J$. Virol. 1994, 68, 1494-1500.

19. Stumpf, M.P.; Pybus, O.G. Genetic diversity and models of viral evolution for the hepatitis C virus. FEMS Microbiol. Lett. 2002, 214, 143-152. 
20. Neumann, A.U.; Lam, N.P.; Dahari, H.; Gretch, D.R.; Wiley, T.E.; Layden, T.J.; Perelson, A.S. Hepatitis $\mathrm{C}$ viral dynamics in vivo and the antiviral efficacy of interferon- $\alpha$ therapy. Science 1998, 282, 103-107.

21. Erickson, A.L.; Kimura, Y.; Igarashi, S.; Eichelberger, J.; Houghton, M.; Sidney, J.; McKinney, D.; Sette, A.; Hughes, A.L.; Walker, C.M. The outcome of hepatitis C virus infection is predicted by escape mutations in epitopes targeted by cytotoxic $\mathrm{T}$ lymphocytes. Immunity 2001, 15, 883-895.

22. Bowen, D.G.; Walker, C.M. Mutational escape from CD8+ T cell immunity: HCV evolution, from chimpanzees to man. J. Exp. Med. 2005, 201, 1709-1714.

23. Uebelhoer, L.; Han, J.H.; Callendret, B.; Mateu, G.; Shoukry, N.H.; Hanson, H.L.; Rice, C.M.; Walker, C.M.; Grakoui, A. Stable cytotoxic T cell escape mutation in hepatitis C virus is linked to maintenance of viral fitness. PLoS. Pathog. 2008, 4, 1-15.

24. von Hahn, T.; Yoon, J.C.; Alter, H.; Rice, C.M.; Rehermann, B.; Balfe, P.; McKeating, J.A. Hepatitis $\mathrm{C}$ virus continuously escapes from neutralizing antibody and T-cell responses during chronic infection in vivo. Gastroenterology 2007, 132, 667-678.

25. Puig, M.; Mihalik, K.; Tilton, J.C.; Williams, O.; Merchlinsky, M.; Connors, M.; Feinstone, S.M.; Major, M.E. CD4+ immune escape and subsequent T-cell failure following chimpanzee immunization against hepatitis $\mathrm{C}$ virus. Hepatology 2006, 44, 736-745.

26. Folgori, A.; Capone, S.; Ruggeri, L.; Meola, A.; Sporeno, E.; Ercole, B.B.; Pezzanera, M.; Tafi, R.; Arcuri, M.; Fattori, E.; Lahm, A.; Luzzago, A.; Vitelli, A.; Colloca, S.; Cortese, R.; Nicosia, A. A T-cell HCV vaccine eliciting effective immunity against heterologous virus challenge in chimpanzees. Nat. Med. 2006, 12, 190-197.

27. Logvinoff, C.; Major, M.E.; Oldach, D.; Heyward, S.; Talal, A.; Balfe, P.; Feinstone, S.M.; Alter, H.; Rice, C.M.; McKeating, J.A. Neutralizing antibody response during acute and chronic hepatitis C virus infection. Proc. Natl. Acad. Sci. USA 2004, 101, 10149-10154.

28. Owsianka, A.; Tarr, A.W.; Juttla, V.S.; Lavillette, D.; Bartosch, B.; Cosset, F.L.; Ball, J.K.; Patel, A.H. Monoclonal antibody AP33 defines a broadly neutralizing epitope on the hepatitis C virus E2 envelope glycoprotein. J. Virol. 2005, 79, 11095-11104.

29. Tarr, A.W.; Owsianka, A.M.; Timms, J.M.; McClure, C.P.; Brown, R.J.; Hickling, T.P.; Pietschmann, T.; Bartenschlager, R.; Patel, A.H.; Ball, J.K. Characterization of the hepatitis C virus E2 epitope defined by the broadly neutralizing monoclonal antibody AP33. Hepatology 2006, 43, 592-601.

30. Law, M.; Maruyama, T.; Lewis, J.; Giang, E.; Tarr, A.W.; Stamataki, Z.; Gastaminza, P.; Chisari, F.V.; Jones, I.M.; Fox, R.I.; Ball, J.K.; McKeating, J.A.; Kneteman, N.M.; Burton, D.R. Broadly neutralizing antibodies protect against hepatitis $\mathrm{C}$ virus quasispecies challenge. Nat. Med. 2008, 14, 25-27.

31. Dahari, H.; Major, M.; Zhang, X.; Mihalik, K.; Rice, C.M.; Perelson, A.S.; Feinstone, S.M.; Neumann, A.U. Mathematical modeling of primary hepatitis $\mathrm{C}$ infection: noncytolytic clearance and early blockage of virion production. Gastroenterology 2005, 128, 1056-1066.

32. Major, M.E.; Dahari, H.; Mihalik, K.; Puig, M.; Rice, C.M.; Neumann, A.U.; Feinstone, S.M. Hepatitis $\mathrm{C}$ virus kinetics and host responses associated with disease and outcome of infection in chimpanzees. Hepatology 2004, 39, 1709-1720. 
33. Prince, A.M.; Pawlotsky, J.M.; Soulier, A.; Tobler, L.; Brotman, B.; Pfahler, W.; Lee, D.H.; Li, L.; Shata, M.T. Hepatitis C virus replication kinetics in chimpanzees with self-limited and chronic infections. J. Viral Hepat. 2004, 11, 236-242.

34. Shoukry, N.H.; Grakoui, A.; Houghton, M.; Chien, D.Y.; Ghrayeb, J.; Reimann, K.A.; Walker, C.M. Memory CD8+ $\mathrm{T}$ cells are required for protection from persistent hepatitis $\mathrm{C}$ virus infection. J. Exp. Med. 2003, 197, 1645-1655.

35. Thimme, R.; Bukh, J.; Spangenberg, H.C.; Wieland, S.; Pemberton, J.; Steiger, C.; Govindarajan, S.; Purcell, R.H.; Chisari, F.V. Viral and immunological determinants of hepatitis C virus clearance, persistence, and disease. Proc. Natl. Acad. Sci. USA 2002, 99, 15661-15668.

36. Farci, P.; Alter, H.J.; Govindarajan, S.; Wong, D.C.; Engle, R.; Lesniewski, R.; Mushahwar, I.K.; Desai, S.M.; Miller, R.H.; Ogata, N.; Purcell, R.H. Lack of protective immunity against reinfection with hepatitis C virus. Science 1992, 258, 140.

37. Prince, A.M.; Brotman, B.; Huima, T.; Pascual, D.; Jaffery, M.; Inchauspe, G. Immunity in hepatitis C infection. J. Infect. Dis. 1992, 165, 438-443.

38. Bassett, S.E.; Guerra, B.; Brasky, K.; Miskovsky, E.; Houghton, M.; Klimpel, G.R.; Lanford, R.E. Protective immune response to hepatitis $\mathrm{C}$ virus in chimpanzees rechallenged following clearance of primary infection. Hepatology 2001, 33, 1479-1487.

39. Major, M.E.; Mihalik, K.; Puig, M.; Rehermann, B.; Nascimbeni, M.; Rice, C.M.; Feinstone, S.M. Previously infected and recovered chimpanzees exhibit rapid responses that control hepatitis C virus replication upon rechallenge. J. Virol. 2002, 76, 6586-6595.

40. Mehta, S.H.; Cox, A.; Hoover, D.R.; Wang, X.H.; Mao, Q.; Ray, S.; Strathdee, S.A.; Vlahov, D.; Thomas, D.L. Protection against persistence of hepatitis C. Lancet 2002, 359, 1478-1483.

41. Bukh, J.; Thimme, R.; Meunier, J.C.; Faulk, K.; Spangenberg, H.C.; Chang, K.M.; Satterfield, W.; Chisari, F.V.; Purcell, R.H. Previously infected chimpanzees are not consistently protected against reinfection or persistent infection after reexposure to the identical hepatitis $\mathrm{C}$ virus strain. J. Virol. 2008, 82, 8183-8195.

42. Lanford, R.E.; Guerra, B.; Chavez, D.; Bigger, C.; Brasky, K.M.; Wang, X.H.; Ray, S.C.; Thomas, D.L. Cross-genotype immunity to hepatitis C virus. J. Virol. 2004, 78, 1575-1581.

43. Weiner, A.J.; Paliard, X.; Selby, M.J.; Medina-Selby, A.; Coit, D.; Nguyen, S.; Kansopon, J.; Arian, C.L.; Ng, P.; Tucker, J.; Lee, C.T.; Polakos, N.K.; Han, J.; Wong, S.; Lu, H.H.; Rosenberg, S.; Brasky, K.M.; Chien, D.; Kuo, G.; Houghton, M. Intrahepatic genetic inoculation of hepatitis C virus RNA confers cross-protective immunity. J. Virol. 2001, 75, 7142-7148.

44. Diepolder, H.M.; Zachoval, R.; Hoffmann, R.M.; Wierenga, E.A.; Santantonio, T.; Jung, M.C.; Eichenlaub, D.; Pape, G.R. Possible mechanism involving T-lymphocyte response to nonstructural protein 3 in viral clearance in acute hepatitis C virus infection. Lancet 1995, 346, 1006-1007.

45. Diepolder, H.M.; Gerlach, J.T.; Zachoval, R.; Hoffmann, R.M.; Jung, M.C.; Wierenga, E.A.; Scholtz, S.; Santantonio, T.; Houghton, M.; Southwood, S.; Sette, A.; Pape, G.R. Immunodominant CD4+ T-cell epitope within nonstructural protein 3 in acute hepatitis $\mathrm{C}$ virus infection. J. Virol. 1997, 71, 6011-6019.

46. Gerlach, J.T.; Diepolder, H.M.; Jung, M.C.; Gruener, N.H.; Schraut, W.W.; Zachoval, R.; Hoffmann, R.; Schirren, C.A.; Santantonio, T.; Pape, G.R. Recurrence of hepatitis C virus after 
loss of virus-specific CD4(+) T- cell response in acute hepatitis C. Gastroenterology 1999, 117, 933-941.

47. Wertheimer, A.M.; Miner, C.; Lewinsohn, D.M.; Sasaki, A.W.; Kaufman, E.; Rosen, H.R. Novel CD4+ and CD8+ T-cell determinants within the NS3 protein in subjects with spontaneously resolved HCV infection. Hepatology 2003, 37, 577-589.

48. Lechner, F.; Wong, D.K.; Dunbar, P.R.; Chapman, R.; Chung, R.T.; Dohrenwend, P.; Robbins, G.; Phillips, R.; Klenerman, P.; Walker, B.D. Analysis of successful immune responses in persons infected with hepatitis C virus. J. Exp. Med. 2000, 191, 1499-1512.

49. Thimme, R.; Oldach, D.; Chang, K.M.; Steiger, C.; Ray, S.C.; Chisari, F.V. Determinants of viral clearance and persistence during acute hepatitis C virus infection. J. Exp. Med. 2001, 194, 1395-1406.

50. Bowen, D.G.; Walker, C.M. Adaptive immune responses in acute and chronic hepatitis C virus infection. Nature 2005, 436, 946-952.

51. Takaki, A.; Wiese, M.; Maertens, G.; Depla, E.; Seifert, U.; Liebetrau, A.; Miller, J.L.; Manns, M.P.; Rehermann, B. Cellular immune responses persist and humoral responses decrease two decades after recovery from a single-source outbreak of hepatitis C. Nat. Med. 2000, 6, 578-582.

52. Grakoui, A.; Shoukry, N.H.; Woollard, D.J.; Han, J.H.; Hanson, H.L.; Ghrayeb, J.; Murthy, K.K.; Rice, C.M.; Walker, C.M. HCV persistence and immune evasion in the absence of memory T cell help. Science 2003, 302, 659-662.

53. Nascimbeni, M.; Mizukoshi, E.; Bosmann, M.; Major, M.E.; Mihalik, K.; Rice, C.M.; Feinstone, S.M.; Rehermann, B. Kinetics of CD4+ and CD8+ memory T-cell responses during hepatitis C virus rechallenge of previously recovered chimpanzees. J. Virol. 2003, 77, 4781-4793.

54. Bartosch, B.; Dubuisson, J.; Cosset, F.L. Infectious hepatitis C virus pseudo-particles containing functional E1-E2 envelope protein complexes. J. Exp. Med. 2003, 197, 633-642.

55. Hsu, M.; Zhang, J.; Flint, M.; Logvinoff, C.; Cheng-Mayer, C.; Rice, C.M.; McKeating, J.A. Hepatitis $\mathrm{C}$ virus glycoproteins mediate $\mathrm{pH}$-dependent cell entry of pseudotyped retroviral particles. Proc. Natl. Acad. Sci. USA 2003, 100, 7271-7276.

56. Wakita, T.; Pietschmann, T.; Kato, T.; Date, T.; Miyamoto, M.; Zhao, Z.; Murthy, K.; Habermann, A.; Krausslich, H.G.; Mizokami, M.; Bartenschlager, R.; Liang, T.J. Production of infectious hepatitis $\mathrm{C}$ virus in tissue culture from a cloned viral genome. Nat. Med. 2005, 11, 791-796.

57. Lindenbach, B.D.; Evans, M.J.; Syder, A.J.; Wolk, B.; Tellinghuisen, T.L.; Liu, C.C.; Maruyama, T.; Hynes, R.O.; Burton, D.R.; McKeating, J.A.; Rice, C.M. Complete replication of hepatitis C virus in cell culture. Science 2005, 309, 623-626.

58. Kato, T.; Matsumura, T.; Heller, T.; SAITO, S.; Sapp, R.K.; Murthy, K.; Wakita, T.; Liang, T.J. Production of infectious hepatitis $\mathrm{C}$ virus of various genotypes in cell cultures. J. Virol. 2007, 81, 4405-4411.

59. Gottwein, J.M.; Scheel, T.K.; Hoegh, A.M.; Lademann, J.B.; Eugen-Olsen, J.; Lisby, G.; Bukh, J. Robust hepatitis $\mathrm{C}$ genotype 3 a cell culture releasing adapted intergenotypic $3 \mathrm{a} / 2 \mathrm{a}$ (S52/JFH1) viruses. Gastroenterology 2007, 133, 1614-1626.

60. Scheel, T.K.; Gottwein, J.M.; Jensen, T.B.; Prentoe, J.C.; Hoegh, A.M.; Alter, H.J.; EugenOlsen, J.; Bukh, J. Development of JFH1-based cell culture systems for hepatitis C virus 
genotype $4 \mathrm{a}$ and evidence for cross-genotype neutralization. Proc. Natl. Acad. Sci. USA 2008, 105, 997-1002.

61. Jensen, T.B.; Gottwein, J.M.; Scheel, T.K.; Hoegh, A.M.; Eugen-Olsen, J.; Bukh, J. Highly efficient JFH1-based cell-culture system for hepatitis $\mathrm{C}$ virus genotype 5a: failure of homologous neutralizing-antibody treatment to control infection. J. Infect. Dis. 2008, 198, 1756-1765.

62. Bartosch, B.; Bukh, J.; Meunier, J.C.; Granier, C.; Engle, R.E.; Blackwelder, W.C.; Emerson, S.U.; Cosset, F.L.; Purcell, R.H. In vitro assay for neutralizing antibody to hepatitis $\mathrm{C}$ virus: evidence for broadly conserved neutralization epitopes. Proc. Natl. Acad. Sci. USA 2003, 100, 14199-14204.

63. Pestka, J.M.; Zeisel, M.B.; Blaser, E.; Schurmann, P.; Bartosch, B.; Cosset, F.L.; Patel, A.H.; Meisel, H.; Baumert, J.; Viazov, S.; Rispeter, K.; Blum, H.E.; Roggendorf, M.; Baumert, T.F. Rapid induction of virus-neutralizing antibodies and viral clearance in a single-source outbreak of hepatitis C. Proc. Natl. Acad. Sci. USA 2007, 104, 6025-6030.

64. Lavillette, D.; Morice, Y.; Germanidis, G.; Donot, P.; Soulier, A.; Pagkalos, E.; Sakellariou, G.; Intrator, L.; Bartosch, B.; Pawlotsky, J.M.; Cosset, F.L. Human serum facilitates hepatitis C virus infection, and neutralizing responses inversely correlate with viral replication kinetics at the acute phase of hepatitis C virus infection. J. Virol. 2005, 79, 6023-6034.

65. Dowd, K.A.; Netski, D.M.; Wang, X.H.; Cox, A.L.; Ray, S.C. Selection pressure from neutralizing antibodies drives sequence evolution during acute infection with hepatitis $\mathrm{C}$ virus. Gastroenterology 2009, 136, 2377-2386.

66. Meunier, J.C.; Engle, R.E.; Faulk, K.; Zhao, M.; Bartosch, B.; Alter, H.; Emerson, S.U.; Cosset, F.L.; Purcell, R.H.; Bukh, J. Evidence for cross-genotype neutralization of hepatitis C virus pseudo-particles and enhancement of infectivity by apolipoprotein C1. Proc. Natl. Acad. Sci. USA 2005, 102, 4560-4565.

67. Farci, P.; Alter, H.J.; Wong, D.C.; Miller, R.H.; Govindarajan, S.; Engle, R.; Shapiro, M.; Purcell, R.H. Prevention of hepatitis C virus infection in chimpanzees after antibody-mediated in vitro neutralization. Proc. Natl. Acad. Sci. USA 1994, 91, 7792-7796.

68. Krawczynski, K.; Alter, M.J.; Tankersley, D.L.; Beach, M.; Robertson, B.H.; Lambert, S.; Kuo, G.; Spelbring, J.E.; Meeks, E.; Sinha, S.; Carson, D.A. Effect of immune globulin on the prevention of experimental hepatitis C virus infection. J. Infect. Dis. 1996, 173, 822-828.

69. Yu, M.Y.; Bartosch, B.; Zhang, P.; Guo, Z.P.; Renzi, P.M.; Shen, L.M.; Granier, C.; Feinstone, S.M.; Cosset, F.L.; Purcell, R.H. Neutralizing antibodies to hepatitis C virus (HCV) in immune globulins derived from anti-HCV-positive plasma. Proc. Natl. Acad. Sci. USA 2004, 101, 7705-7710.

70. Youn, J.W.; Hu, Y.W.; Tricoche, N.; Pfahler, W.; Shata, M.T.; Dreux, M.; Cosset, F.L.; Folgori, A.; Lee, D.H.; Brotman, B.; Prince, A.M. Evidence for protection against chronic hepatitis C virus infection in chimpanzees by immunization with replicating recombinant vaccinia virus. $J$. Virol. 2008, 82, 10896-10905.

71. Zubkova, I.; Choi, Y.H.; Chang, E.; Pirollo, K.; Uren, T.; Watanabe, H.; Wells, F.; Kachko, A.; Krawczynski, K.; Major, M.E. T-cell vaccines that elicit effective immune responses against $\mathrm{HCV}$ in chimpanzees may create greater immune pressure for viral mutation. Vaccine 2009, 27, 2594-2602. 
72. Choo, Q.L.; Kuo, G.; Ralston, R.; Weiner, A.; Chien, D.; Van Nest, G.; Han, J.; Berger, K.; Thudium, K.; Kuo, C. Vaccination of chimpanzees against infection by the hepatitis $\mathrm{C}$ virus. Proc. Natl. Acad. Sci. USA 1994, 91, 1294-1298.

73. Coates, S.; Choo, Q. L.; Kuo, G.; Crawford, K.; Dong, C.; Wininger, M.; Weiner, A. J.; Berger, K.; Wong, S.; Ralston, R.; Morandi, M.; Pileri, P.; Rosa, D.; Muchmore, E.; Mahony, J.; Brasky, K.M.; Purceli, R.H.; Abrignani, S.; Houghton, M. Protection of Chimpanzees against Heterologous 1a Viral Challenge using a gpE1/gpE2 Heterodimer Vaccine. In Proceedings of the 11th International Symposium on Viral Hepatitis and Liver Disease, Sydney, Australia, 6-10 April, 2003; Jilbert, A.R., Grgacic, E., Vickery, K., Burrell, C.J., Cossart, Y.E., Eds; Australian Center for Hepatitis Virology: Sydney, 2004; pp. 118-123.

74. Forns, X.; Payette, P.J.; Ma, X.; Satterfield, W.; Eder, G.; Mushahwar, I.K.; Govindarajan, S.; Davis, H.L.; Emerson, S.U.; Purcell, R.H.; Bukh, J. Vaccination of chimpanzees with plasmid DNA encoding the hepatitis $\mathrm{C}$ virus (HCV) envelope $\mathrm{E} 2$ protein modified the infection after challenge with homologous monoclonal HCV. Hepatology 2000, 32, 618-625.

75. Elmowalid, G.A.; Qiao, M.; Jeong, S.H.; Borg, B.B.; Baumert, T.F.; Sapp, R.K.; Hu, Z.; Murthy, K.; Liang, T.J. Immunization with hepatitis $\mathrm{C}$ virus-like particles results in control of hepatitis $\mathrm{C}$ virus infection in chimpanzees. Proc. Natl. Acad. Sci. U SA 2007, 104, 8427-8432.

76. Puig, M.; Major, M.E.; Mihalik, K.; Yu, M.Y.; Feinstone, S.M. Immunization of chimpanzees with an envelope protein-based vaccine enhances specific humoral and cellular immune responses that delay hepatitis C virus infection. Vaccine 2004, 22, 991-1000.

77. Rollier, C.; Depla, E.; Drexhage, J.A.; Verschoor, E.J.; Verstrepen, B.E.; Fatmi, A.; Brinster, C.; Fournillier, A.; Whelan, J.A.; Whelan, M.; Jacobs, D.; Maertens, G.; Inchauspe, G.; Heeney, J.L. Control of heterologous hepatitis $\mathrm{C}$ virus infection in chimpanzees is associated with the quality of vaccine-induced peripheral T-helper immune response. J. Virol. 2004, 78, 187-196.

78. Youn, J.W.; Park, S.H.; Lavillette, D.; Cosset, F.L.; Yang, S.H.; Lee, C.G.; Jin, H.T.; Kim, C.M.; Shata, M.T.; Lee, D.H.; Pfahler, W.; Prince, A.M.; Sung, Y.C. Sustained E2 antibody response correlates with reduced peak viremia after hepatitis $\mathrm{C}$ virus infection in the chimpanzee. Hepatology 2005, 42, 1429-1436.

79. Rollier, C.S.; Paranhos-Baccala, G.; Verschoor, E.J.; Verstrepen, B.E.; Drexhage, J.A.; Fagrouch, Z.; Berland, J.L.; Komurian-Pradel, F.; Duverger, B.; Himoudi, N.; Staib, C.; Meyr, M.; Whelan, M.; Whelan, J.A.; Adams, V.C.; Larrea, E.; Riezu, J.I.; Lasarte, J.J.; Bartosch, B.; Cosset, F.L.; Spaan, W.J.; Diepolder, H.M.; Pape, G.R.; Sutter, G.; Inchauspe, G.; Heeney, J.L. Vaccine-induced early control of hepatitis $\mathrm{C}$ virus infection in chimpanzees fails to impact on hepatic PD-1 and chronicity. Hepatology 2007, 45, 602-613.

80. Zhu, Y.D.; Heath, J.; Collins, J.; Greene, T.; Antipa, L.; Rota, P.; Bellini, W.; McChesney, M. Experimental measles. II. Infection and immunity in the rhesus macaque. Virology 1997, 233, 85-92.

81. Betts, R.F.; Treanor, J.J. Approaches to improved influenza vaccination. Vaccine 2000, 18, 1690-1695.

82. Onorato, I.M.; Modlin, J.F.; McBean, A.M.; Thoms, M.L.; Losonsky, G.A.; Bernier, R.H. Mucosal immunity induced by enhance-potency inactivated and oral polio vaccines. J. Infect. Dis. 1991, 163, 1-6. 
83. Ross, R.S.; Viazov, S.O.; Hoffmann, S.; Roggendorf, M. Performance characteristics of a transcription-mediated nucleic acid amplification assay for qualitative detection of hepatitis $\mathrm{C}$ virus RNA. J. Clin. Lab Anal. 2001, 15, 308-313.

84. Werzberger, A.; Mensch, B.; Kuter, B.; Brown, L.; Lewis, J.; Sitrin, R.; Miller, W.; Shouval, D.; Wiens, B.; Calandra, G. A controlled trial of a formalin-inactivated hepatitis A vaccine in healthy children. N. Engl. J. Med. 1992, 327, 453-457.

85. Innis, B.L.; Snitbhan, R.; Kunasol, P.; Laorakpongse, T.; Poopatanakool, W.; Kozik, C.A.; Suntayakorn, S.; Suknuntapong, T.; Safary, A.; Tang, D.B. Protection against hepatitis A by an inactivated vaccine. JAMA 1994, 271, 1328-1334.

86. Zuckerman, A.J. Immunization against hepatitis B. Br. Med. Bull. 1990, 46, 383-398.

87. Koutsky, L.A.; Ault, K.A.; Wheeler, C.M.; Brown, D.R.; Barr, E.; Alvarez, F.B. Chiacchierini, L.M.; Jansen, K.U. A controlled trial of a human papillomavirus type 16 vaccine. N. Engl. J. Med. 2002, 347, 1645-1651.

88. Alter, H.J.; Seeff, L.B. Recovery, persistence, and sequelae in hepatitis C virus infection: a perspective on long-term outcome. Semin. Liver Dis. 2000, 20, 17-35.

89. Seeff, L.B. Natural history of chronic hepatitis C. Hepatology 2002, 36, S35-S46.

90. Zhang, P.; Zhong, L.; Struble, E.B.; Watanabe, H.; Kachko, A.; Mihalik, K.; Virata-Theimer, M.L.; Alter, H.J.; Feinstone, S.; Major, M. Depletion of interfering antibodies in chronic hepatitis $\mathrm{C}$ patients and vaccinated chimpanzees reveals broad cross-genotype neutralizing activity. Proc. Natl. Acad. Sci. USA 2009, 106, 7537-7541.

91. Zhang, P.; Wu, C.G.; Mihalik, K.; Virata-Theimer, M.L.; Yu, M.Y.; Alter, H.J.; Feinstone, S.M. Hepatitis $\mathrm{C}$ virus epitope-specific neutralizing antibodies in Igs prepared from human plasma. Proc. Natl. Acad. Sci. USA 2007, 104, 8449-8454.

92. Seder, R.A.; Ahmed, R. Similarities and differences in CD4+ and CD8+ effector and memory T cell generation. Nat. Immunol. 2003, 4, 835-842.

93. Harari, A.; Bart, P.A.; Stohr, W.; Tapia, G.; Garcia, M.; Medjitna-Rais, E.; Burnet, S.; Cellerai, C.; Erlwein, O.; Barber, T.; Moog, C.; Liljestrom, P.; Wagner, R.; Wolf, H.; Kraehenbuhl, J.P.; Esteban, M.; Heeney, J.; Frachette, M.J.; Tartaglia, J.; McCormack, S.; Babiker, A.; Weber, J.; Pantaleo, G. An HIV-1 clade C DNA prime, NYVAC boost vaccine regimen induces reliable, polyfunctional, and long-lasting T cell responses. J. Exp. Med. 2008, 205, 63-77.

94. Thacker, E.E.; Timares, L.; Matthews, Q.L. Strategies to overcome host immunity to adenovirus vectors in vaccine development. Exp. Rev. Vaccines. 2009, 8, 761-777.

95. Abraham, J.D.; Himoudi, N.; Kien, F.; Berland, J.L.; Codran, A.; Bartosch, B.; Baumert, T.; Paranhos-Baccala, G.; Schuster, C.; Inchauspe, G.; Kieny, M.P. Comparative immunogenicity analysis of modified vaccinia Ankara vectors expressing native or modified forms of hepatitis $\mathrm{C}$ virus E1 and E2 glycoproteins. Vaccine 2004, 22, 3917-3928.

96. Earl, P.L.; Americo, J.L.; Wyatt, L.S.; Espenshade, O.; Bassler, J.; Gong, K.; Lin, S.; Peters, E.; Rhodes, L., Jr.; Spano, Y.E.; Silvera, P.M.; Moss, B. Rapid protection in a monkeypox model by a single injection of a replication-deficient vaccinia virus. Proc. Natl. Acad. Sci. USA 2008, 105, 10889-10894.

97. Brinster, C.; Chen, M.; Boucreux, D.; Paranhos-Baccala, G.; Liljestrom, P.; Lemmonier, F.; Inchauspe, G. Hepatitis $\mathrm{C}$ virus non-structural protein 3-specific cellular immune responses 
following single or combined immunization with DNA or recombinant Semliki Forest virus particles. J. Gen. Virol. 2002, 83, 369-381.

98. Lin, Y.; Kwon, T.; Polo, J.; Zhu, Y.F.; Coates, S.; Crawford, K.; Dong, C.; Wininger, M.; Hall, J.; Selby, M.; Coit, D.; Medina-Selby, A.; McCoin, C.; Ng, P.; Drane, D.; Chien, D.; Han, J.; Vajdy, M.; Houghton, M. Induction of broad CD4+ and CD8+ T-cell responses and crossneutralizing antibodies against hepatitis $\mathrm{C}$ virus by vaccination with Th1-adjuvanted polypeptides followed by defective alphaviral particles expressing envelope glycoproteins gpE1 and gpE2 and nonstructural proteins 3, 4, and 5. J. Virol. 2008, 82, 7492-7503.

99. Xiong, C.; Levis, R.; Shen, P.; Schlesinger, S.; Rice, C.M.; Huang, H.V. Sindbis virus: an efficient, broad host range vector for gene expression in animal cells. Science 1989, 243, 1188-1191.

100. Leitner, W.W.; Hwang, L.N.; deVeer, M.J.; Zhou, A.; Silverman, R.H.; Williams, B.R.; Dubensky, T.W.; Ying, H.; Restifo, N.P. Alphavirus-based DNA vaccine breaks immunological tolerance by activating innate antiviral pathways. Nat. Med. 2003, 9, 33-39.

101. Perri, S.; Greer, C.E.; Thudium, K.; Doe, B.; Legg, H.; Liu, H.; Romero, R.E.; Tang, Z.; Bin, Q.; Dubensky, T.W., Jr.; Vajdy, M.; Otten, G.R.; Polo, J.M. An alphavirus replicon particle chimera derived from venezuelan equine encephalitis and sindbis viruses is a potent gene-based vaccine delivery vector. J. Virol. 2003, 77, 10394-10403.

102. Martin, P.; Simon, B.; Lone, Y.C.; Chatel, L.; Barry, R.; Inchauspe, G.; Fournillier, A. A vectorbased minigene vaccine approach results in strong induction of T-cell responses specific of hepatitis C virus. Vaccine 2008, 26, 2471-2481.

103. Jaeckel, E.; Cornberg, M.; Wedemeyer, H.; Santantonio, T.; Mayer, J.; Zankel, M.; Pastore, G.; Dietrich, M.; Trautwein, C.; Manns, M.P. Treatment of acute hepatitis C with interferon alfa-2b. N. Engl. J. Med. 2001, 345, 1452-1457.

104. Lohmann, V.; Korner, F.; Koch, J.; Herian, U.; Theilmann, L.; Bartenschlager, R. Replication of subgenomic hepatitis C virus RNAs in a hepatoma cell line. Science 1999, 285, 110-113.

105. Blight, K.J.; Kolykhalov, A.A.; Rice, C.M. Efficient initiation of HCV RNA replication in cell culture. Science 2000, 290, 1972-1974.

106. Yutani, S.; Yamada, A.; Yoshida, K.; Takao, Y.; Tamura, M.; Komatsu, N.; Ide, T.; Tanaka, M.; Sata, M.; Itoh, K. Phase I clinical study of a personalized peptide vaccination for patients infected with hepatitis $\mathrm{C}$ virus (HCV) $1 \mathrm{~b}$ who failed to respond to interferon-based therapy. Vaccine 2007, 25, 7429-7435.

107. Klade, C.S.; Wedemeyer, H.; Berg, T.; Hinrichsen, H.; Cholewinska, G.; Zeuzem, S.; Blum, H.; Buschle, M.; Jelovcan, S.; Buerger, V.; Tauber, E.; Frisch, J.; Manns, M.P. Therapeutic vaccination of chronic hepatitis $\mathrm{C}$ nonresponder patients with the peptide vaccine IC41. Gastroenterology 2008, 134, 1385-1395.

108. Fournillier, A.; Gerossier, E.; Evlache, A.; Martin, P.; Bain, C.; Schmidt, D.; Silvestre N; Julien, M.; Habersetzer, F.; Zarski, J.; Leroy, V.; Maynard-Muet, M.; Trepo, C.; Agathon, D.; Bonnefoy, J.; Burtin, B.; Honnet, G.; Inchauspe, G. Therapeutic vaccination against HCV: pre-clinical and clinical evaluation of a novel MVA-based vaccine. In 15th International Symposium on Hepatitis C and Related Viruses, San Antonio, Texas, USA, 5 October 2008. 
109. Nevens, F.; Roskams, T.; Van Vlierberghe, H.; Horsmans, Y.; Sprengers, D.; Elewaut, A.; Desmet, V.; Leroux-Roels, G.; Quinaux, E.; Depla, E.; Dincq, S.; Vander, S.C.; Maertens, G.; Hulstaert, F. A pilot study of therapeutic vaccination with envelope protein E1 in 35 patients with chronic hepatitis C. Hepatology 2003, 38, 1289-1296.

110. Alvarez-Lajonchere, L.; Shoukry, N.H.; Gra, B.; Amador-Canizares, Y.; Helle, F.; Bedard, N.; Guerra, I.; Drouin, C.; Dubuisson, J.; Gonzalez-Horta, E.E.; Martinez, G.; Marante, J.; Cinza, Z.; Castellanos, M.; Duenas-Carrera, S. Immunogenicity of CIGB-230, a therapeutic DNA vaccine preparation, in HCV-chronically infected individuals in a Phase I clinical trial. J. Viral Hepat. 2009, 16, 156-167.

111. Batdelger, D.; Dandii, D.; Jirathitikal, V.; Bourinbaiar, A.S. Open-label trial of therapeutic immunization with oral V-5 Immunitor (V5) vaccine in patients with chronic hepatitis C. Vaccine 2008, 26, 2733-2737.

112. Wedemeyer, H.; Schuller, E.; Schlaphoff, V.; Stauber, R.E.; Wiegand, J.; Schiefke, I.; Firbas, C.; Jilma, B.; Thursz, M.; Zeuzem, S.; Hofmann, W.P.; Hinrichsen, H.; Tauber, E.; Manns, M.P.; Klade, C.S. Therapeutic vaccine IC41 as late add-on to standard treatment in patients with chronic hepatitis C. Vaccine 2009, in Press.

113. Chua, B.Y.; Eriksson, E.M.; Brown, L.E.; Zeng, W.; Gowans, E.J.; Torresi, J.; Jackson, D.C. A self-adjuvanting lipopeptide-based vaccine candidate for the treatment of hepatitis $\mathrm{C}$ virus infection. Vaccine 2008, 26, 4866-4875.

114. Thammanichanond, D.; Moneer, S.; Yotnda, P.; Aitken, C.; Earnest-Silveira, L.; Jackson, D.; Hellard, M.; McCluskey, J.; Torresi, J.; Bharadwaj, M. Fiber-modified recombinant adenoviral constructs encoding hepatitis $\mathrm{C}$ virus proteins induce potent $\mathrm{HCV}$-specific $\mathrm{T}$ cell response. Clin. Immunol. 2008, 128, 329-339.

115. Leroux-Roels, G.; Depla, E.; Hulstaert, F.; Tobback, L.; Dincq, S.; Desmet, J.; Desombere, I.; Maertens, G. A candidate vaccine based on the hepatitis C E1 protein: tolerability and immunogenicity in healthy volunteers. Vaccine 2004, 22, 3080-3086.

116. Leroux-Roels, G.; Batens, A.H.; Desombere, I.; Van Den, S.B.; Vander, S.C.; Maertens, G.; Hulstaert, F. Immunogenicity and tolerability of intradermal administration of an HCV E1-based vaccine candidate in healthy volunteers and patients with resolved or ongoing chronic $\mathrm{HCV}$ infection. Hum. Vaccin. 2005, 1, 61-65.

117. Polakos, N.K.; Drane, D.; Cox, J.; Ng, P.; Selby, M.J.; Chien, D.; O'Hagan, D.T.; Houghton, M.; Paliard, X. Characterization of hepatitis $\mathrm{C}$ virus core-specific immune responses primed in rhesus macaques by a nonclassical ISCOM vaccine. J. Immunol. 2001, 166, 3589-3598.

118. Pearse, M.J.; Drane, D. ISCOMATRIX adjuvant for antigen delivery. Adv. Drug Deliv. Rev. 2005, 57, 465-474.

119. Drane, D.; Maraskovsky, E.; Gibson, R.; Mitchell, S.; Barnden, M.; Moskwa, A.; Shaw, D.; Gervase, B.; Coates, S.; Houghton, M.; Basser, R. Priming of CD4(+) and CD8(+) T cell responses using a HCV core ISCOMATRIX(TM) vaccine: A phase I study in healthy volunteers. Hum. Vaccin. 2009, 5, 151-157.

120. Fournillier, A.; Gerossier, E.; Evlashev, A.; Schmitt, D.; Simon, B.; Chatel, L.; Martin, P.; Silvestre, N.; Balloul, J.M.; Barry, R.; Inchauspe, G. An accelerated vaccine schedule with a 
poly-antigenic hepatitis $\mathrm{C}$ virus MVA-based candidate vaccine induces potent, long lasting and in vivo cross-reactive $T$ cell responses. Vaccine 2007, 25, 7339-7353.

121. Inchauspe, G.; Michel, M.L. Vaccines and immunotherapies against hepatitis B and hepatitis C viruses. J. Viral Hepat. 2007, 14 Suppl. 1, 97-103.

(C) 2009 by the authors; licensee Molecular Diversity Preservation International, Basel, Switzerland. This article is an open-access article distributed under the terms and conditions of the Creative Commons Attribution license (http://creativecommons.org/licenses/by/3.0/). 